\title{
USE OF INFORMATION AND COMMUNICATION TECHNOLOGIES IN THE INCLUSIVE PROCESS OF EDUCATIONAL INSTITUTIONS
}

\author{
OLENA BUDNYK, MYKHAYLO KOTYK
}

\begin{abstract}
The article substantiates the relevance of the problem of using information and communication technologies (ICT) to partially solve the problem of accessibility to education for certain categories of people with disabilities and improving the quality of educational services. The need for introducing open access repositories with educational and scientific content is emphasized, which will allow alternative ways of gaining knowledge despite time or space constraints. The advantages and disadvantages of using ICT in the inclusive process are outlined, and their main types are proposed which can be used to support inclusive education. The features of creating an effective computer-integrated learning environment in the inclusive process are identified, forms and methods of working with children with special needs using ICT are presented. The authors display the results of a survey of teachers regarding their attitude to this problem and their professional skills in using ICT in the educational process of a general secondary educational institution. The article focuses on the necessity to study and promote assistive technologies in inclusive learning, which are developed today in the world to enable people with disabilities to get education and their social integration. These technologies give people the opportunity to learn effectively, receive new information, communicate through devices to control computer equipment, including remotely; reading electrical signals, etc. The difficulties of implementing ICT in inclusive education of Ukraine are substantiated, among them: high cost of ICT, especially assistive technologies; lack of computer software at educational institutions, lack of powerful internet, especially in rural areas; low level of digital literacy of teachers, especially regarding the use of special training tools; often their conservative attitude to innovations, online communication with students with special educational needs; the lack of support for such students as for the use of specialized ICTs and others.
\end{abstract}

Keywords: inclusive education, ICT, children with disabilities, computer integrated learning environment, general secondary education.

\section{INTRODUCTION}

According to the World Health Organization, there are around one billion people with disabilities worldwide. In Europe and America, they are every fifth person. And because they are less likely to find work, the poverty rate among these people is twice as high as the average [2]. It is no coincidence that the problem of inclusive education for children in today's urban world is extremely urgent. This include the physical accessibility of educational institutions for children with special needs, and the 
psychological adaptation of all participants in the educational process to the conditions of inclusion, educational and methodological support for inclusive learning [17; 12]. Thus, of 75 million children in the world who didn't attend school for various reasons, one third are children with disabilities. At the same time, there is a very high level of illiteracy among this category of persons. In particular, in developing countries, exclusion from the education system is much more significant for persons with psycho-physical development disorders, about $97 \%$ of them are neither able to read nor write [8]. The inability to get an education deprives persons with disabilities from getting a profession, decent wages and realization in society. The literacy rate among people with psycho-physical disorders (globally) is only $3 \%$ and unemployment is $80 \%$ [8].

For a partial solution to the problem of accessibility to education for certain categories of persons, improving the quality of education, incl. in distant format, it is advisable to use Information and Communication Technologies (ICT). For this purpose, according to Y. Nosenko, it is time to introduce open access repositories with educational and scientific content, which will allow alternative ways of obtaining knowledge despite time or space constraints. ICT can be a significant driver of positive changes, as their application makes it possible to attract more education participants at a lower cost, to meet the demands of social justice for all populations, it opens wide prospects for improving the quality of education and its accessibility for persons with disabilities, promoting equal access to information and educational services, full and fruitful social integration [12, p. 116-123].

The problem of inclusive education is reflected in scientific works of such domestic scientists as: V. Bondar, I. Kalinichenko A. Kolupaeva, Z. Leniv, V. Synov, O. Taranchenko A. Shevtsov, N. Shwed and others. Socio-pedagogical aspects of teaching children with special needs are partially covered in the studies of : O. Bezpalko, R. Vainola, A Kapskaya, N. Seiko, etc.; the use of ICT in an inclusive process: V. Bykov, Y. Nosenko, M. Mariotti, etc. The issues of organization and development of inclusive learning in different countries were studied by: B. Abery, V. Blândul, A. Bradea, D. Cameron, D. J. Chambers, N. Hui, L. Kincadec, S. Main, P. Sarah, M. Friend, L. Cook, D.A. Hurley-Chamberlain, C. Shamberger, R. Tichá, E. Vickery, J. Njelesani and other.

\section{ANALYSIS AND DisCUSSION}

In many countries, including Eastern Europe, there are some difficulties in reaching inclusion goals due to the inability of primary schools to take into account rapid changes: to introduce information and communication technologies, pedagogical innovations on the principles and content of the organization of training, new strategies of pedagogical interaction on the basis of personally oriented education, etc. In post-Soviet countries, where inclusive education has only begun to be actively implemented in the last decade, it is too difficult to overcome socio-pedagogical stereotypes [6]. After all, implementing an inclusive approach in education involves creating the right balance: providing people with disabilities with proper educational services and realizing personal importance in the school environment (Tichá, Abery, Kincadec) [16, p. 47].

To investigate the real situation of using ICT in inclusive education at Ukrainian schools we carried out a survey. According to the survey results, $99 \%$ of respondents answered yes to our question "Do you use ICT in the process of inclusive teaching" (103 out of 104 all educators). Most respondents think that the use of ICT in teaching children with special educational needs will increase the effectiveness of the educational process: $66.3 \%$ (69 persons) of the total number of respondents; 34 people (32.7\%) answered that the technical means would partially increase the learning outcomes of the students, and only 1 teacher $(1.0 \%)$ did not support this idea.

Results of teachers' responses to the question "What facilities do you consider most appropriate for teaching children with disabilities?" Given on Fig. 1. 


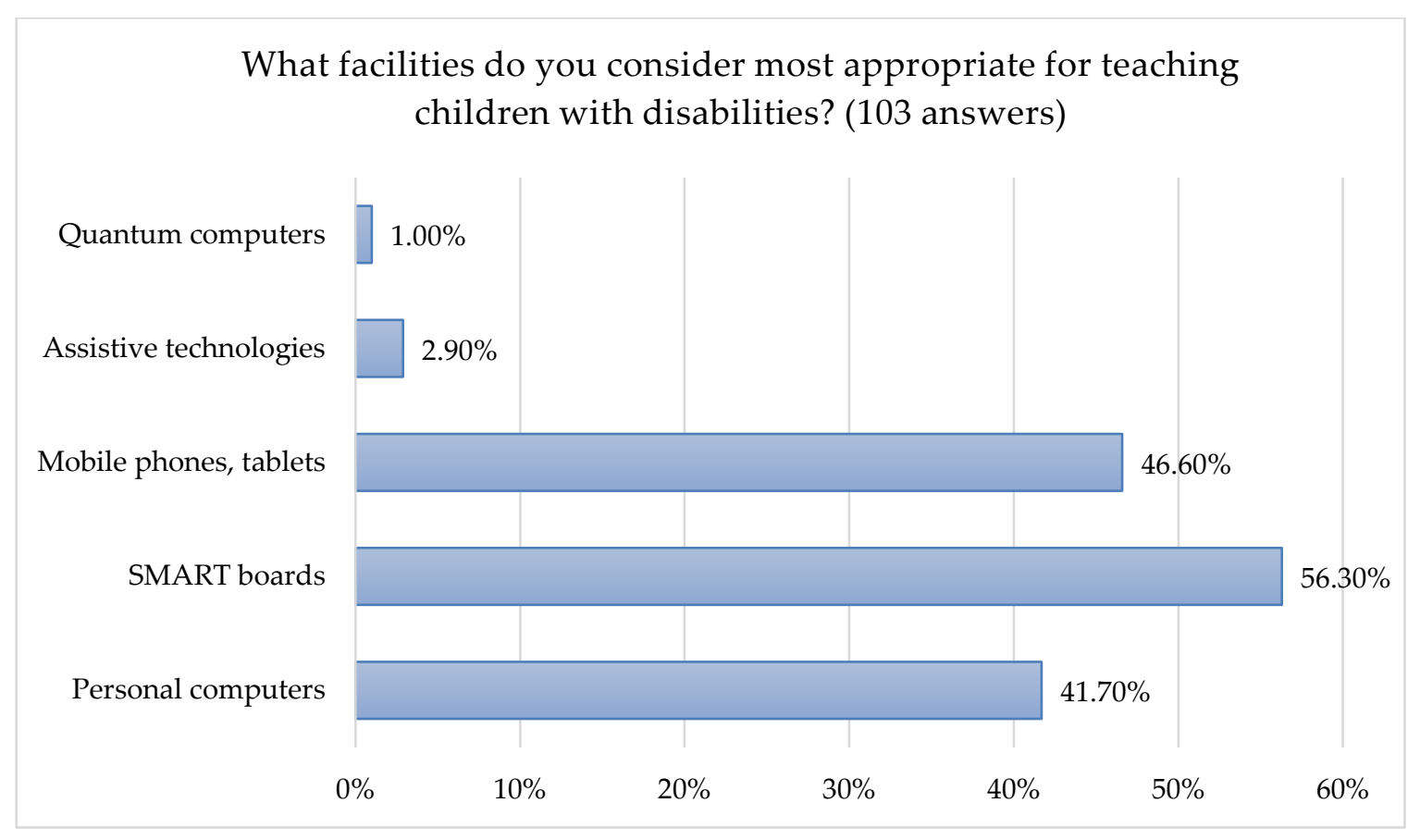

Fig. 1. Technical facilities for teaching children with special educational needs

Personal computers, SMART boards, the Internet today all serve as necessary tools in the teaching process. In addition, SMART technologies for people with special needs can more widely and fully unleash the creative potential of every child. For example, using a projector and an interactive whiteboard allows you to apply a variety of colors as a system of harmoniously interconnected shades of color. Touch tablets are necessary tools for stimulating tactile sensations, interaction with the environment and more.

Thus, among the main types of ICTs suitable for use as a means of supporting inclusive learning are the following:

- standard technologies;

- PCs (desktops, laptops (netbooks), tablets (etc.) with built-in configuration options for people with psycho-physical disorders;

- available data formats, or alternative formats, such as accessible HTML; DAISY

- standard digital format for recording digital audio books (digital talking books);

- braille printers, displays and language synthesizers, etc;

- assistive technologies - hearing aids, screen readers, accessibility keyboards, alternative communication systems, etc. [7].

Personalized Computer Integrated Learning Environment is an open computer integrated learning environment of pedagogical systems, which provides proper ICT infrastructure, (including virtual) targeting at individual information and communication, resource, operational and procedural needs of the participants of the educational process. [3]

Appropriately, a computer-integrated learning environment in an inclusive process is a computerintegrated learning environment in an educational institution, which created a proper ICT infrastructure, the Internet, and adapted educational content to meet the educational needs of students with psycho-physical disorders.

Modern scholars determine the benefits of using ICT in teaching children with disabilities [12, p. 28-29]: general benefits are: expanding student autonomy, overcoming communication barriers in the educational process, creating opportunities to identify and evaluate learning outcomes in a convenient way, taking into account individual characteristics of students and others.

At the same time, a well-integrated computer-based learning environment in an inclusive process has significant advantages, especially for students with disabilities: 
- access to educational resources using ICT as a compensatory tool at their convenient time and place for individual home-based learning, incl. with parents (guardians);

- fulfillment of educational tasks taking into account peculiarities of their development, at their own pace; if necessary - repeated repetition of theoretical or practical material (experiments in virtual laboratories), etc. (in asynchronous mode);

- creation of conditions for personal self-realization, development of digital competence, communicative culture online, etc.;

- increasing students' learning motivation, their interest in mastering new material;

- opportunities for finding different educational information, messaging and multimedia data exchange, etc. It gives access to the following resources: educational, methodological, artistic and scientific texts, multimedia presentations, electronic manuals, computer programs, multimedia projects, test tasks, sound and music files, digital copies and author feature films, audio books, multimedia games and competitions, video master classes, graphic images, photos, tables, cartographic systems, references and more.

We consider the effective aim in pedagogical science and practice to use STEAM-education for teaching children with psychophysical disorders. Among them there are also gifted children who have certain inclinations for the appropriate activity. Today, there are enough IT professionals in the world with limited health options. Moreover, an effective aspect of inclusive education is the identification and recognition of the compensatory capacity of persons with disabilities who, contrary to nosology, have the abilities and inclinations, above all, to activities that require conscientious attitude, diligence, patience, etc. In fact, such is the research activity in the field of STEM education [5].

ICTs provide opportunities for co-operative learning for students with disabilities. We find it extremely important, because activities have a common goal - work together in groups to achieve it and to solve learning tasks. It has a positive effect. It is obvious especially for children with special needs, because they interact with others, feel themselves an inseparable part of the group, can share their knowledge, express their opinions, defend them, make joint decisions, learn to discuss, etc. "The idea of this model is to involve all students in teamwork for the implementation of a task through interdependent and cooperative collaboration. Studies suggest that the effects of cooperative learning proved to be an efficient tool to increase academic achievements of students with and without disabilities" [15].

Modern scientists (Armitage, Pihl, Ryberg) study theoretical, philosophical, pedagogical and aesthetical aspects of the contradictions and interactions between the collective and the individual in creative learning processes. This also applies largely inclusion. Today it is important to develop a student's creative personality, creativity in practical activity, regardless of differences or special needs. At the same time, we involve students with disabilities in partnerships in teams to solve specific learning tasks - Problem Based Learning (PBL). The question is: "In the design process there are always many ways and solutions to solve the same problem, so how can we be sure that we choose the right concept to finding the optimum solution to practical problems? What is the role of PBL in this context?" [1].

It may be important for a team of professionals researching inclusion to model Cooperative Learning in this way, to predict the development of the individual creative abilities of all students according to the purpose of the curriculum. As every child is unique in his or her own development and perception of the world, so two children with the same disorder will respond differently to the same situation, have different cognitive needs, and so on. Therefore, it is important to create an inclusive educational environment at school that encourages students to constructive, collaborative and contextual learning and self-improvement taking into account individual differences and developmental characteristics [6].

According to modern authors (V. Kovalenko, Y. Nosenko, A. Yatsyshyn) it is advisable to use ICT in educational and extracurricular work at practical lessons, in particular: 
- search online information on a given topic (probably both individual and group performance, where each student is offered to collect data on some aspect of the object being studied, after which together with a group to combine the data in a comprehensive description of objects);

- making speeches using presentation tools;

- making presentations using different multimedia (audio, video, animation, etc .;

- organization of thematic groups (for example, for joint implementation of a training project);

- creating a portfolio of your own works (completed creative tasks, educational projects, multimedia presentations, etc.);

- preparation and conducting of surveys on given topics;

- creation of multimedia greeting cards (for personal, professional and other holidays; with wishes for fast recovery to students who are ill, etc.) and their distribution;

- mutual evaluation of students' completed works, discussing them in the form of comments [10, p. 126].

The aim of M. Mariotti's study was to explore the potential of using weStories and iPads with students with autism. WeStories is a unique form of storytelling that helps teach students to tell stories while working on literacy, including reading, writing, communicating, and creating visual images. WeStories requires two or more students work in a group to write and create their own stories using technologies such iPad [11]. This technology has been successfully implemented in the teaching of students with different abilities, as M. Mariotti notes. The essence of it is that students work in groups and create digital stories using iPads. Kids collaborate with one or more other students with special needs together to create weStories. This technology is especially effective for developing social and communicative skills of children with autism and children with typical development [the same source].

It is worth noting that in recent years, the attention of scholars has been focused on iPad as an effective tool for educating children with autistic disorders who have problems with social interaction and communication with their peers. This tool allows you to develop social skills effectively. For this aim the program "Hanging Out" was created. This program explains to students how to invite a friend for a walk and provides advice on how to communicate with friends [9].

In today's context, general secondary education teachers have some difficulties using ICT in inclusion. They were asked the question "What difficulties do you face while using ICT in inclusive education?" We got the following answers:

- insufficient educational and methodological support - 34 persons (30.1\% of respondents);

- low level of training of pedagogical staff to use ICT in inclusion - 25 persons $(24.3 \%)$;

- insufficient computer supply for schools - 23 persons (22.4\%);

- lack of desire to use ICT in education for students with disabilities-17 persons (16.5\%);

- lack of teaching motivation -7 respondents $(6.8 \%)$.

However, teachers are clearly aware of the benefits and feasibility of creating a computer-integrated learning environment in an inclusive process. This creates right conditions for professional growth, distant communication with colleagues and learning from their experience of implementing educational innovations; dissemination of own progressive teaching experience; participation and holding webinars; enhancement of digital competence, culture of work in the information space; improving ICT skills to support effective work with students with special educational needs; opportunities to stimulate students' cognitive interests; enhancing their motivation for learning by updating the content and methods of teaching; introduction of educational innovations using digital tools, etc. For example, according to Y. Nosenko, due to multimedia it is possible to carry out and correct influence on different sensory areas. Materials in electronic format are easier to adapt to students' needs (eg. large font, Braille, etc.) [12, p. 28-29].

Nowadays, there are some interesting technological innovations of improving educational access for people with disabilities and their social integration. Today, scientists around the world are working out assistive technologies that would enable persons with disabilities to study effectively, receive new information, and communicate through devices to control computer devices, including: distantly; reading electrical signals, etc. 
For example, in 2011, Resource Center was established in Ukraine, the center of inclusive education for children and young people with profound visual anomalies. This Center provides methodological, technical, didactic, corrective, advisory and other practical assistance to secondary and higher education institutions, pedagogical staff, inclusive resource centers, parents of blind children, other interested persons. It is interesting that the Center staff has developed their own (Ukrainian) model of inclusive education for blind children, which is based on the experience of Scandinavia (primarily Sweden), partly Canada, as well as the experience of persons with severe visual impairments. This model is tested in various regions of the country by creating and distributing Braille literature, DAISY audio tutorials, video content with audio (animated and feature films), organizing audio courses for guides/actors, and inclusive education courses for general education educators, conducting correctivedevelopmental classes [14]. This helps blind children not only get elementary education, but also integrate into society.

We believe that the organizing of this Centers to assist different categories of persons with disabilities would greatly help, above all, to provide qualitative psychological and pedagogical support and to provide certain ICT materials for successful learning.

Answers to the question "What online resources do you consider to be the most effective in inclusive education?" are shown in Fig. 2.

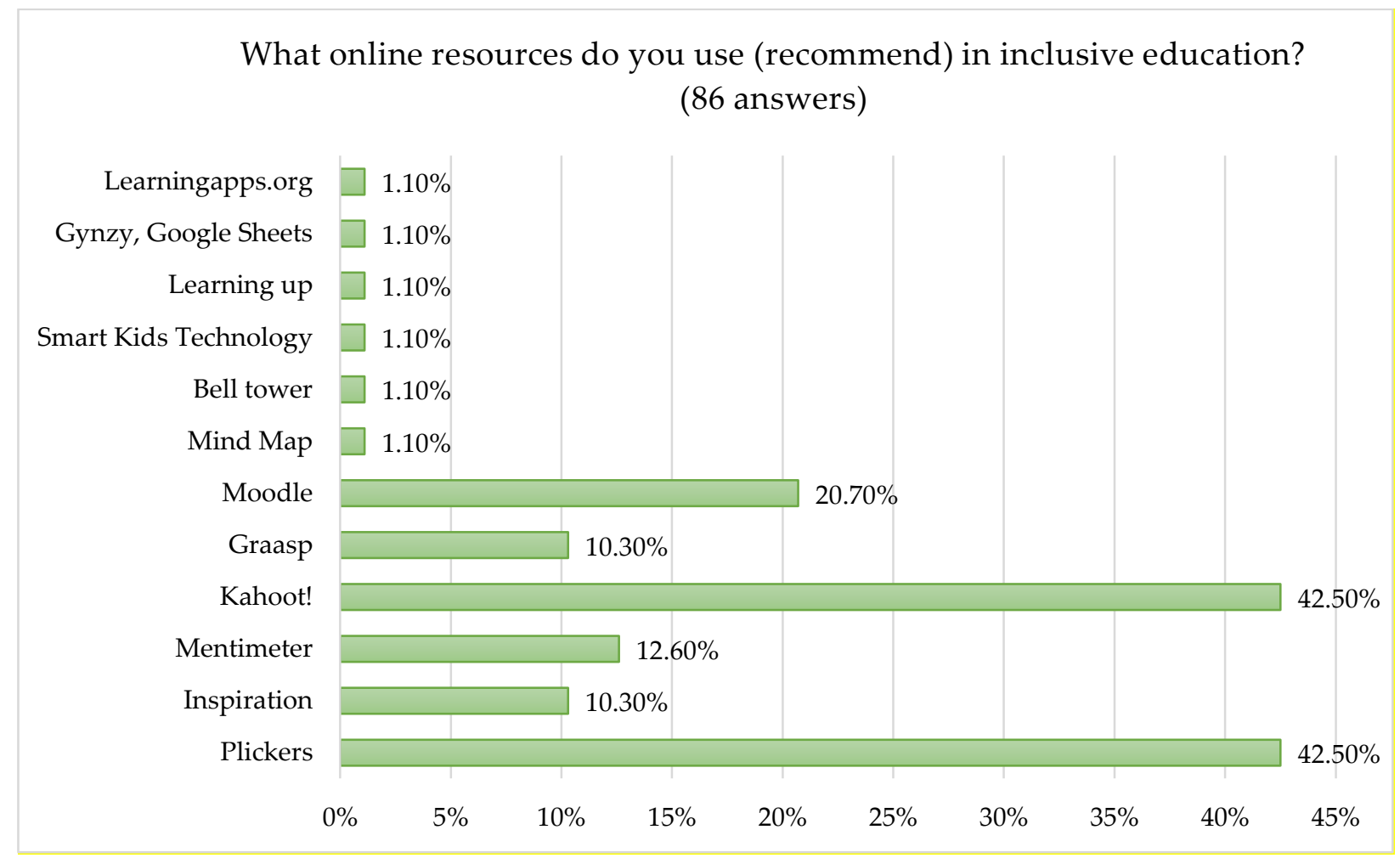

Fig. 2. Online resources that pedagogical staff recommend to use in inclusive children's education

As we can see, teachers mostly use digital tools like: Plickers (for formative assessment of learning outcomes) - 37 persons (42.5\%) and as many educators chose Kahoot! (for audience feedback). Mind Map is also often used while working with students with special needs (one-third of the respondents 32 persons (36.8\%). Much less use: Inspiration, Mentimeter, Graasp, Moodle and others.

\section{CONCLUSIONS}

For some category of students with special educational needs, e-learning is the only way to acquire new knowledge, to meet their cognitive needs, to realize themselves in a personal or professional way, to gain access to communication online with other participants in the educational process in an 
accessible and convenient way for them. At the same time, it is advisable to use ICT in the education of persons with disabilities in the following directions:

- as support for the educational process in educational establishments;

- in extracurricular educational work, non-formal education;

- as support for non- formal education and self-education of children and young people.

Among the main difficulties in implementing ICT in inclusive education in Ukraine are the following:

1) high cost and / or little supply of ICT, especially assistive technologies [13, p. 30]; lack of computers at general secondary education institutions, lack of powerful internet, especially in rural (mountainous) areas;

2) low level of digital competence of pedagogical staff regarding the use of ICT in inclusive education;

3) insufficient educational and methodological support for the formation and development of digital competence of pupils in the conditions of inclusion;

4) conservative teaching staff's attitude towards innovations, in particular regarding the use of ICT in the educational process, online communication with students with special educational needs;

5) insufficient support (or lack of support) of students with psychophysical disorders to use specialized ICT;

6) lack of educators' awareness of digital educational resources that should be used in an inclusive process, etc.

Therefore, the use of ICT in the educational process is a new social challenge, and inclusive learning is a necessity. Digital technologies and instruments provide access to a variety of educational resources as a compensatory tool for people with disabilities, as well as opportunities to study distantly at home; completing of tasks taking into account individual and psychological peculiarities of development; opportunities for online experiments in virtual (remote) laboratories; expanding autonomy while overcoming communication barriers in the educational process, creating opportunities to diversify ways to evaluate learning outcomes, and more. We believe that despite many difficulties, there are more benefits using ICT in teaching children with disabilities. Therefore, it is time to create a properly computer-integrated learning environment in an inclusive classroom at New Ukrainian School or University.

\section{REFERENCES}

[1] Armitage A., Pihl O., Ryberg T. PBL and creative processes. Journal of Problem Based Learning in Higher Education, 3 (1) (2015): Special Issue: PBL and Creative Processes, I-IV. doi: 10.5278/ojs.jpblhe.v3i1.1199

[2] Belton P. How technology helps people with disabilities. Available at: https://www.bbc.com/ukrainian/science/2016/02/160202_tech_disability_ko (in Ukrainian)

[3] Bykov V.Y. Technologies of cloud computing, ICT-outsourcing and new functions of ICT-departments of educational and scientific institutions. Information Technology in Education, 10 (2011), 8-23. doi: 10.14308/ite000260 (in Ukrainian)

[4] Bykov V., Leshchenko M. Digital humanistic pedagogy of open education summary. Theory and Practice of Social Systems Management, 4 (2016), 115-130. (in Ukrainian)

[5] Budnyk O. Inclusive learning: the socio-pedagogical context of the problem. In: Zasenko V.V., Kolupaeva A.A. (Eds.) Education of persons with special needs: ways of development, 13. Nasha drukarnia, Kyiv, 2017, 71-80. (in Ukrainian)

[6] Budnyk O., Sydoriv S. Social and pedagogical aspects of the development of inclusive education. Sociální pedagogika/Social Education, 7 (1) (2019), 36-48. doi: 10.7441/soced.2019.07.01.03 
[7] ICT for inclusion: reaching more students more effectively. Available at: http://iite.unesco.org/pics/publications/ru/files/3214675.pdf (in Russian)

[8] Inclusive education: the way to the future. 48th Session of the International Conference on Education: Final Report. UNESCO, 2008. Available at: http://www.ibe.unesco.org/fileadmin/user_upload/ Policy_Dialogue/48th_ICE/ICE_FINAL_REPORT_rus.pdf (in Russian)

[9] Farrell J. Spurwink Launches App for Teens and Adults on the Autism Spectrum. Available at: http://www.prweb.com/releases/ 2011/02/prweb5049044.htm

[10] Kovalenko V., Nosenko Y., Yatsyshyn A. Electronic social networks as a means of supporting the educational process and social and pedagogical work with students who have functional limitations. In: Geta A., Zaika V., Kovalenko V. et al. Modern ICT tools for supporting inclusive learning. PUET, Poltava, 2018, 119-127. (in Ukrainian)

[11] Mariotti M. An exploration of using ipads and digital storytelling through westorieswith students who have autism. (2012). HIM 1990-2015. 1278. Available at: http://stars.library.ucf.edu/honorstheses19902015/1278

[12] Nosenko Y. Electronic Inclusion as an Effective Strategy for Ensuring Accessibility and Openness of Education. Pedagogical Innovations: Ideas, Realities, Perspectives, 2 (17) (2016), 116-123. (in Ukrainian)

[13] Nosenko Y. The role of information and communication technology in supporting inclusive learning. In: Geta A., Zaika V., Kovalenko V. et al. Modern ICT tools for supporting inclusive learning. PUET, Poltava, 2018, 24-32. (in Ukrainian)

[14] About the Resource Center for Educational Information Technology for Persons with Disabilities. Available at: http://lp.edu.ua/rcoit/pro-resursnyy-centr (in Ukrainian)

[15] Suleymanov F. Issues of Inclusive Education: Some aspects to be considered. Electronic Journal for Inclusive Education, 3 (4) (2015). Available at: https://corescholar.libraries.wright.edu/cgi/viewcontent. cgi?article $=1175 \&$ context $=$ ejie

[16] Tichá R., Abery B., Kincade L. Educational practices and strategies that promote inclusion: Examples from the U.S. Sociální pedagogika/Social Education, 6 (2) (2018), 43-62. doi: 10.7441/soced.2018.06.02.03

[17] Vasianovych H., Budnyk O. The Philosophical Foundations of the Researches of the Inclusive Education. Journal of Vasyl Stefanyk Precarpathian National University, 6 (1) (2019), 9-18. doi: 10.15330/jpnu.6.1.9-18

Address: Olena Budnyk, Mykhaylo Kotyk, Vasyl Stefanyk Precarpathian National University, 57, Shevchenko Str., Ivano-Frankivsk, 76018, Ukraine.

E-mail: olena.budnyk@pnu.edu.ua; mykhaylo.kotyk@pnu.edu.ua

Received: 17.01.2020; revised: 15.02.2020.

Будник Олена, Котик Михайло. Використання інформаційно-комунікаційних технологій в інкдюзивному процесі закладу освіти. Журнал Прикарпатського університету імені Василя Стефаника, 7 (1) (2020), 15-23.

У статті обгрунтовано актуальність проблеми використання інформаційно-комунікаційних технологій (IКT) для часткового вирішення проблеми доступності до освіти для окремих категорій осіб 3 інвалідністю та підвищення якості надання освітніх послуг. Наголошено на потребі запровадження репозиторіїв відкритого доступу з освітнім і науковим контентом, що умождивить альтернативні шляхи отримання знань попри часові чи просторові обмеження. Висвітлено переваги та негативні сторони використання IКТ в інклюзивному процесі, подано основні їх типи для використання як засобу підтримки інклюзивного навчання. Визначено особливості створення ефективного комп'ютерно інтегрованого навчального середовища в інклюзивному процесі, подано форми і методи роботи 3 дітьми 3 особливими потребами 3 використанням IKT. Авторами 
представлено результати опитування педагогів щодо їхнього ставдення до цієї проблеми та професійної майстерності у використанні IКТ в освітньому процесі закладу загальної середньої освіти. У статті акцентовано на потребі вивчення й популяризації допоміжних технологій в інкдюзивному навчанні, які сьогодні розроблені у світі для поліпшення доступу людей 3 обмеженими можливостями до освіти та їх соціального інтегрування. Ці технології дають змогу особам 3 обмеженими можливостями ефективно навчатися, отримувати нову інформацію, комунікувати через прилади для керування комп'ютерним обладнанням, у т.ч. дистанційно; зчитування електричних сигналів і т.п. Обгрунтовано труднощі упровадження IКТ в інклюзивній освіті України, серед яких: висока вартість IKT, особливо асистивних (допоміжних) технологій; недостатне комп'ютерне забезпечення закладів освіти, відсутність потужного інтернету, передусім у сільській місцевості; низький рівень цифрової грамотності педагогів, особливо щодо використання спеціальних засобів навчання; часто їх консервативне ставлення до інновацій, онлайн комунікації з учнями 3 особливими освітніми потребами; недостатня підтримка таких учнів щодо використання спеціалізованих IКТ та iH.

Кдючові слова: інклюзивна освіта, IКТ, діти з обмеженими можливостями, комп'ютерно інтегроване навчальне середовище, заклад загадьної середньої освіти, інклюзивне навчання.
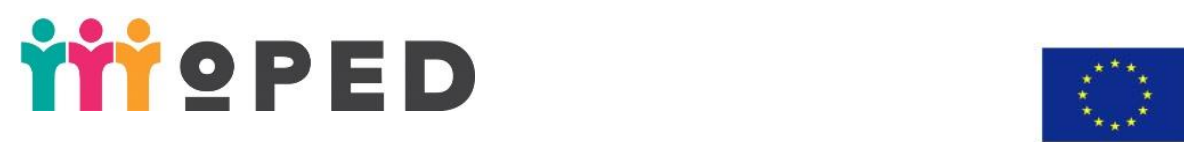

Co-funded by the Erasmus+ Programme of the European Union

"The article has been prepared in the framework of the Erasmus+ project "MoPED - Modernization of Pedagogical Higher Education by Innovative Teaching Instruments", No. 586098-EPP-1-2017-1-UAEPPKA2-CBHE-JP. This project has been funded with support from the European Commission. This publication reflects the views only of the author, and the Commission cannot be held responsible for any use which may be made of the information contained therein". 